\title{
IAMJ
}

INTERNATIONAL

AYURVEDIC

MEDICAL JOURNAL

ISSN: 23205091

Impact Factor: 5.344

\section{SIDHMAKUSHTA: A DISEASE REVIEW}

\section{Sruthi Sreedhar}

PG Scholar, KVG Ayurveda Medical College, Sullia, Mangalore, Karnataka, India

Corresponding Author: dr.sruthi.sreedhar@gmail.com

\section{https://doi.org/10.46607/iamj3708102020}

(Published online: October 2020)

Open Access

(C) International Ayurvedic Medical Journal, India 2020

Article Received: 17/09/2020 - Peer Reviewed: 29/09/2020 - Accepted for Publication: 03/10/2020

\section{Check for updates}

\section{ABSTRACT}

Skin disorder constitutes one of the largest groups of health problems in general practice. Good skin is an integral part of health. In Ayurveda, all skin diseases are explained under a single heading of Kushta. Sidhma Kushta is an Oupasargikaroga. All Kushta is due to aggravation of Tridosas. These aggravated Dosha vitiates Dushyas like Twak, Raktha, Mamsa and Ambu by circulating in them and produce Vaivarnya. ${ }^{1}$ According to Susrutha, whenever the aggravated Doshas get stagnated, Mandalas appear at that site. ${ }^{2}$ Kushta are innumerable in number based on the permutation and combination of Doshas and Dushyas, but mainly they are divided into seven Maha Kushta and eleven Kshudra Kushta. Sidhma is a variety of Kushtaroga according to all the authors of Brihathrayi and Laghutrayi. However, Charaka classified it under Maha Kushta and other Acharyas like Susrutha and Vagbhata brought it under Kshudra Kushta. By Dalhana's commentary it can be understood that Sidhma is of two types, Sidhma Kushta and Pushpitha Sidhma. ${ }^{3}$ Symptoms of Tinea versicolor are similar to that of Lakshanas of Sidhma Kushta, Acharya Susrutha has said that Krimi is also one of the cause for Kushta and Tinea versicolor is a superficial mycoses caused by a fungi called Malassezia furfur. Understanding of Lakshanas and Samprapti plays an important role in the diagnosis, prognosis and treatment of the disease. So, an attempt is made to analyse and understand the concept of Sidhma Kushta.

Keywords: Kushta, Sidhma, Tinea versicolor. 


\section{INTRODUCTION}

Sidhma is a variety of Kushta. It is commonly seen in all the seasons; aggravation of symptoms can be seen in Greeshma Ritu and also in the humid climate. Sidhma is a Vata Kaphaja Kushta. It has symptoms like Vaivarnya (Swetha, Tamra), Kandu and Rajaprapthi. General causative factors explained in Kushta are to be considered for Sidhma Kushta also. According to Rasendra Sara Sangraha, by treating one Kushta patient the Vaidya gets Punya of Koti Kanyadaana (one crore marriages), offering Tarpana to ancestors at the banks of river ganga or benefits gained while residing in Kailasa. ${ }^{4}$ It shows the importance of proper treatment. Kushnaati Rogan Kush + Hani Kushiti i.e. Kushta gives an ugly look to the body. When vitiated Doshas provokes the four body elements \& if this derangement of seven Dravyas is not treated then disease is formed inside the body which manifests itself on the outermost part of the body which produces Kushta. According to Arunadatta, Kushta is defined as that which causes disfigurement to the body. Bhrajaka Pitta is located in this layer and gives color and texture to the skin. According to Charaka, Sidhma is occurs in the Triteeyaka layer of skin, but Susrutha explains it is in the Avabhasini layer.

\section{Review of literature:}

Charaka Samhitha: Acharya Charaka has mentioned 18 types of Kushta, which are further divided into Maha Kushta and Kshudra Kushta. Sidhma Kushta is explained in Maha Kushta.

Susrutha Samhitha: Acharya Susrutha is the $1^{\text {st }}$ one who stated clearly anuvamshikata \& Krimi as a causative factor of Kushta. He explained Dhatugatatwa \& Dhatuanupravesh of Kushta. Susrutha explained Sidhma Kushta under Kshudra Kushta.

Ashtangahridaya: In Ashtanga Hridaya Vagbhata has given explanation about Kushtaroga in the $14^{\text {th }}$ chapter of NidhanaStana and treatment is explained under ChikitsaStana $19^{\text {th }}$ chapter.

BhelaSamhitha: In this Samhitha $5^{\text {th }}$ and $6^{\text {th }}$ chapter of NidanaStana and Chikitsasthana Kushta roga has been explained. Acharya indicated specially polluted water as an etiological factor of Kushta.

Vangasena: Has explained about Sidhma under Kushta Chikitsa Adhyaya.

Yogaratnakara: Information of Kushta is given in the same chapter Nidana, Chikitsa and Sadhyasaadhyatha of Sidhma Kushta is explained. Yogaratnakara has explained Sidhma Kushta under Maha Kushta.

Kashyapa Samhitha: Kushta is described in Kushta Chikitsa chapter. A total of 18 types of Kushta have been described under Sadhya and Asadhya categories. Sidhma is included in Sadhya Kushta.

Madhava Nidana: Madhavakara in the chapter of Kushta Nidana, described Sidhma as Maha Kushta.

Saranghadhara Samhita: No detailed description is available in this Samhita except a running reference of Sidhma while indication of some Yogas.

Chakradatta: In Chakradatta $50^{\text {th }}$ chapter the Kushtaroga detailed treatment schedule is given Sidhma Kushta is also explained in the chapter.

Bhavaprakasha: Bhavamisra has described Kushta similar to Charaka in Bhavaprakasha madhyama khanda $54^{\text {th }}$ in the same chapter Sidhma Kushta.

Nidana Panchaka: There is no specific Nidana explained for Sidhma Kushta, so the general factors told for Kushta can be considered. According to Madhukosha, Nidana are classified into

Bahya Nidana; Abhyantara Nidana; Nidanarthakara rogas.

Vishesha Nidana for Kushta: Apart from other Nidana, Acharya Shodala have mentioned Vishesha Nidana for manifestation of Kushta

Tila taila; Kulattha; Valmika; Mahishadadhi.

Samprapti: A proper understanding of Samprapti is vital in planning the treatment of disease. All Acharyas have explained common Samprapti for Kushta. According to Charaka, due to Nidana, Doshas get aggravated which further vitiates Twacha, Mamsa, Raktha and Lasika and produce Kushta. ${ }^{5}$ According to Vagbhata, Samprapti is of two phases, due to Bahya Nidana Dosas it aggravates, and they reach the Shakha through Tiryak Vaha Siras. They circulate within these Dushyas to produce 
Vaivarnatha of Twak in the initial stage of disease. ${ }^{6}$ Even after appearance of discoloration, if it is not treated then they will reach the deeper Dhatus and produce symptoms like Sweda, Kooda, Samkotha. These will create ideal environment for development of Krimi and these Krimi wil destruct Loma, Twak, Snayu, Dhamani, Tarunasthi gradually in the later stages of the disease. According to Susrutha, the Vata gets aggravated by the Nidanas, and will combine with aggravated Pitta and Kapha to enter into the Siras, which are transversely spread over the surface of the body, wherever these Doshas get stagnated they produce Mandalas. These aggravated Dosas if not treated, it will vitiate deeper to become severe forms of Kushta. ${ }^{7}$

Poorvarupa: Poorvarupas are the indicator of impending disease. There is no specific Poorvarupa mentioned for Sidhma Kushta. The general Lakshana of Sidhma Kushta when appeared in mild form those are considered as Poorvarupa of Sidhma Kushta.

Lakshanas: According to Charaka, Sidhma is a type of Maha Kushta, the signs and symptoms are Parusha Aruna Varna, the periphery it is fissured and then in center it is smooth white and red shade. It appears in large number and there is less pain, itching, burning sensation, Puya, Lasika, Srava i.e., pus and serous discharge. There is formation of ulcers and sluggish in nature and get infected by Krimi. It appears like flower of Alabu and it is at Kapha Vata predominance. ${ }^{8}$ In Chikitsa Stana of Charaka, symptoms such as Shweta, Tamra Varna, Tanu, Rajoghrushta and Alabu Pushpavat are explained. ${ }^{9}$ According to Acharya Susrutha, Sidhma is characterized by Kandu, Shweta Varna, Apayi, Tanu, and generally this disease occurs in Urdhwakaya. ${ }^{10}$ Susrutha considers Sidhma as Kaphahdika Kushta. According to Vagbhata, the Sidhma Kushta appears to be externally dry, internally it is moist in nature and while scratching scales like dust will be seen. It is smooth to touch, skin over the effected part is Tanu (soft) and it looks like Daugdhika Pushpa with whitish brown colour and most commonly appears in Urdhwakaya. Dosha involved is Vata Kapha. ${ }^{11}$ According to Bhavaprakasha, Sidhma Kushta Lakshanas include white and copper colored skin followed by the scales and appears like Alabu Kusuma. The variety of symptomatology in Sidhma lesions are mainly seen over Urapradesa. Madhavakara, Yogaratnakara. Vangasena also explained the signs and symptoms similar to Acharya Charaka. Acharya Bhela emphasized the signs and symptoms of Sidhma Kushta in $5^{\text {th }}$ chapter of Kushta Nidana \& $6^{\text {th }}$ chapter of Kushta Chikitsa adhyaya. He considered Sidhma as one of Kaphaja Kushta with symptoms like Mandala which are Pandu Varna Pankiloshta, Twakuttana, Ruksha and Tanu. ${ }^{12}$

\begin{tabular}{|l|l|l|l|l|l|}
\hline Character of Sidhma & Cha $($ Chi, Ni) & Su & AH & KS & Bh. Sam \\
\hline Parushatwak & + & - & - & - & - \\
\hline Arunavarna & + & - & - & - & - \\
\hline Visheerna & + & - & - & - & - \\
\hline Bahir tanu & + & + & - & - & - \\
\hline Atisnigdha & + & - & + & - & - \\
\hline Shukla raktavabhasini & + & - & - & - & - \\
\hline Bahu & + & - & - & - & - \\
\hline Alpavedana & + & - & - & - & - \\
\hline Alpakandu & + & + & + & - & - \\
\hline Alpadaha & + & - & - & - & - \\
\hline Alpapuyalasikasravi & + & - & - & - & - \\
\hline Laghusamudhani & + & - & - & - & - \\
\hline Alpabhedi & + & - & - & - & - \\
\hline AlpaKrimi & + & - & - & - & - \\
\hline Alabupushpavat & + & - & - & + & - \\
\hline
\end{tabular}




\begin{tabular}{|l|l|l|l|l|l|}
\hline Sweta & + & + & - & - & - \\
\hline Apaka & - & + & - & - & + \\
\hline Prayashaurdhwakaaya & + & + & + & - & - \\
\hline Varuni pushpin pushpavat & - & - & - & + & - \\
\hline Uttitatwak & - & - & - & - & - \\
\hline RookshaMandalani & - & - & - & - & - \\
\hline Rajoghristham & + & - & + & + & - \\
\hline Nisravi & - & + & - & - & - \\
\hline Bahiruksham & - & - & + & - & - \\
\hline Slakshnasparsham & - & - & + & - & - \\
\hline Dougdhikapushpavat & - & - & + & - & - \\
\hline Pichila & - & - & - & - & + \\
\hline Madhuvarna & - & - & - & - & + \\
\hline & & & & & - \\
\hline
\end{tabular}

Upashaya: No specific Upashaya of Sidhma is mentioned in classical texts.

\section{Sadhya Asadhyatha (Cha.Su10/6-7)}

After the diagnosis and before the treatment it is important to know the prognosis of disease. If the person suffers from Sidhma Kushta with deranged Vata and Kapha or from any one of the Doshas ,then it is easily curable. ${ }^{13}$ Based on the involvement of Dhatus, Acharya Susrutha has explained that the person who has full control over his sense organs and the Kushta in which only Twak, Rakta and Mamsa are affected, are Sadhya varieties. If it reaches deeper Dhatus, then they should be considered as Asadhya. ${ }^{14}$ As per Madhavakara he considered those varieties of Kushta in which Meda, AsthiandMajjaDhatu are involved as Yapya. ${ }^{15}$

The main Vikrithi lies in the superficial Dhathus, so Sidhma is a Sadya Vyadhi.

\section{Differential diagnosis:}

1. Shwithra/swetha Kushta (Kaphaja Kushta) Swetha and Guru with Kandu (A.Sa:Ni:14)

2. Mandala - Swetha, Raktha, Stira, Snigdha, Utsanna Mandala, Anyonya Samyukta

3. Pundarika - Swetha, Raktha, Pundarika Dalopamam, Utswedam, Raga.

Chikitsa: Acharya Charaka mentioned that all Kushta are Tridoshaja so treatment should be done only after considering the dominance of Dosa. Predominant dose should be treated first. Charaka explained three types of Chikitsa. ${ }^{16}$
- Samshodana: Kushta occur due to Doshas Bahulyatha, these Doshas are Tiryagaami and very difficult to treat by Shamana therapy.

- Shamana: Shamana is done when the Dosha aggravation is comparatively less. Acharya Charaka has advised Shamana with Tiktha \& Kashaya Dravyas after administration of proper Shodhana.

- Nidana Parivarjana: Abstaining from the etiological factors is very important. It stops the further progression of the disease by restricting vitiation of Doshas.

According to Charaka, the planning of treatment depends on the predominance of Dosha involved. If the disease is Vata predominant, Sarpi is advocated, Virechana and Rakthamokshana are recommended if the disease is Pitta predominant and Vamana is indicated for Kapha Dosha.${ }^{17}$ Once Shodhana is done, Snehapana is advised by Acharya Charaka as the patient would have become weak and also may lead to aggravation of Vata. Hence to provide strength to the patient and to control the Vata, Snehapana is done. ${ }^{18}$ Susrutha explained treatment with particular period of time, such as every fifteen days Vamana Karma, every month Virechana Karma, every six months Raktha mokshana every third day Nasya Karma. ${ }^{19}$ Vagbhata's opinion is similar to Susrutha. According to Rasendra Sara Sangraha, Panchakarma is the first line of treatment. Vamana is done once in 15 days, Virechana is done once in a month, Rakthamokshana is done once in 6 months and every 7th day Nasya is 
done. But when Kushta is of recent origin, symptoms and Dosha aggravation are minimal then Alpa Kriya can be done. ${ }^{20}$

Pathya Apathya of Sidhma Kushta: Pathya Apathya has a very important role in Ayurveda, as it is believed that without Pathyaapathya treatment won't get good result. Sidhma Kushta does not have separate Pathyaapathya, because it is understood that the Pathyaapathya mentioned in Kushtaroga is related to Sidhma Kushta also.

Pathya Ahara: Sashtikashali Yava, Kudag, Khadira, Jangalamamsa, Khadirodaka, Tiktarasa, Pattola, Brihatiphala, Kakamachi, Nimbapathra, Lashun, Punarnava, Meshasringi, Bhallathaka, Triphala Chithraka etc.

Vihara: Vishrama

Apathyaaahara: Guru Anna, Virudha Anna, Vishamam bhojana drava Anna, Navanna, Dugdha, Vidahi Anna, Guda, Amla Kabani Katurasa, Tila, Masha

Vihara: Swedanakarma, Strisamsarga, Ativyavaya According to Susrutha, one who is suffering Kushta should use Khadira in daily life for the purpose of bathing, drinking and along with food. Apart from this Susrutha explained one who is suffering from Kushta should maintain cleanliness by cutting unwanted hairs $\&$ nails and should take medicines regularly. ${ }^{21}$

Modern aspects of Sidhma: Sidhma can be compared with Pityriasis versicolor in modern medical science.

Synonyms: Tinea versicolor, Dermatomycosis, Furfuracea. It is a mild chronic fungal infection of skin caused by Pityrosporum species. It is characterized by discrete scaly discoloured or depigmented areas mainly on the upper trunk. The patient usually complaints only of a patchy and varying change of skin colour may be associated with mild irritation. The primary lesion is a sharply demarcated macule, sometimes slightly erythematous but characterized by fine branny scaling. Typically, the eruption shows large confluent areas, scattered oval patches \& outlying macule. The site most commonly affected is the upper trunk but is also often spread to the upper arms, the neck and the abdomen. Lesions occur in the axillae, groins, thighs and genetalia which extends down to the forearms, on to the back of hands and into the popliteal fossae. Facial \& scalp involvement are well recognized in the tropics. The colour of the scales may vary from pale ochre to medium brown. In the untanned white skin the affected areas are darker than normal but they fail to respond to light exposure and in the sun tanned subject, the abnormal skin is commonly paler spontaneously or as a result of treatment, the residual depigmentation may remain for many months without scaling. In hypopigmented macules, Malassezia furfur is in the cornified layer produces a sun protection factor, Hyperpigmented macules coloured hyphae of Malassezia furfur is in the cornified layer. Orthokeratosis type of scales are present. ${ }^{22}$

\section{DISCUSSION}

Acharya Susrutha has explained Sidhma under Kshudra Kushta. The characteristic site and colour of the lesions are mentioned same as Charaka ChikitsaSthana. Kandu is the symptom mentioned by Susrutha only. One more specific symptoms Apayi ${ }^{23}$ which means Akastakari i.e., not troublesome to the patient has been mentioned. It shows low severity of Sidhma. Among Saptha Dravyas mentioned for the causation of Kushta, the Tridosas Vata, Pitta, Kapha and two Dushyas (Rasa, Raktha) plays an important role in the management of Sidhma Kushta. The role of Mamsa and Lasika seems to be less. Charaka has considered Sidhma Kushta under the heading of Vata Kaphaja Kushta. On other hand, Susrutha has stressed the role of Kapha in the pathogenesis of Sidhma Kushta. When we go through the Lakshanas of Dhathugata Kushta, it is evident that only two Dushyas among the four are involved in the pathogenesis of Sidhma (Su.Ni). Lakshanas like Vivarnyata, Rukshata, Kandu are Twak gata Kushta Lakshana. Kandu is Lakshana of Rakthagata Kushta also. By this we can consider that only Twak and Raktha are involved. By Nidana Dosas get aggravated and they get localised in the superficial layer of skin i.e., Avabhasini. Aggravated Kapha increases the Kledatha to produce Swedaavaran and also provide suitable environment for the development of Krimi in 
it (which is similar to that of pathology of Tinea versicolor). Raja Prapthi is due to Vata diseases. In brief Vata, Kapha, Twak and Raktha involve in the pathogenesis of Sidhma Kushta.

\section{CONCLUSION}

Sidhma is one among the Ekadasa Kshudra Kushta described by Susrutha and Vagbhata. Charaka mentioned Sidhma under Sapta Maha Kushta, which has similar signs and symptoms as those mentioned by Susrutha except Srava. Susrutha's explanation of Sidhma Kushta is more relevant practically. When the Doshas are in the superficial Dhatu and the aggravation is relatively less, then it can be considered as Sidhma explained by Susrutha. Similarly, when the Dosha aggravation is severe and the deeper Dhatus are involved, then it can be considered as Sidhma explained by Charaka. Sidhma explained by Charaka in Nidanasthana is similar to that of Tinea corporis which is much severe that Tinea versicolor (Susruthoktha Sidhma). All Kushta are Tridoshaja. Most of the symptoms of Sidhma Kushta is Kapha Vata dominant. Acharya Charaka has described four Dushyas as Twak, Raktha, Mamsa and Lasika Dhathu which are primarily involved in the manifestation of Kushta. In Sidhma most symptoms are due to Rasa Raktha Dushti, so the primary Dushyas involved are Rasa and Raktha. Srothas involved are Rasavaha Srothas and Raktha Vaha Srothas. Treatment is always based on the predominance of Dosha.

\section{REFERENCES}

1. Vaidya Yadavji Trikamji Acharya edited Charaka Samhitha of Agnivesa, with Ayurvedadipika Commentary of Sri Chakrapanidatta, Pub-: Choukhamba Surbharathi Prakashan, Varanasi, Reprint 2014, Chikitsasthana Chapter 7, Sloka No 9, Page No 450.

2. Vaidya Jadavji Trikamji Acharya edited Susrutha Samhita, with Commentary Nibhandasangraha of Dalhana, NidanaStana, Chapter 5, Sloka No 3, Pub -: Chaukhamba Surbharathi Prakashan, Varanasi, Edition, Reprint 2014, Page No 216

3. Vaidya Jadavji Trikamji Acharya edited Susrutha Samhita with Commentary Nibhandasangraha of
Dalhana, NidanaStana, Chapter 5, Sloka No 12, Pub-: Chaukhamba Surbharathi Prakashan, Varanasi, Edition, Reprint 2014, Page No 285

4. Dr Ashok. D. Sattute English translated Rasendra Sara Sangraha of Gopal Krishna, Chowkhamba Krishnadas Academy, Varanasi Edition 2003 Kushta Roga Chikitsa, Shloka No 1-2, Page no - 584

5. Vaidya Yadavji Trikamji Acharya edited Charaka Samhitha Of Agnivesa with Ayurvedadipika Commentary of Sri Chakrapanidatta,Pub-: Choukhamba Surbharathi Prakashan, Varanasi, Reprint 2014, ChikitsaStana ,Chapter 7, Sloka No 9, Page No 450

6. Pt, Hari Sadashiva Sastri Paradakara edited Ashtanga Hrudaya Of Vagbhata with Commentary of Sarvangasundari of Arunadatta and Ayurveda Rasayana Of Hemadri, Pub; Chaukhamba Surbarati Prakashan, Varanasi, Edition Reprint 2014, NidanaStana, Chapter 14, Sloka No 2-3, Page No 52

7. Vaidya Jadavji Trikamji Acharya edited Susrutha Samhita with Commentary Nibhandasangraha of Dalhana, NidanaStana, Chapter 5, Sloka No3, Pub:Chaukhamba Surbharathi Prakashan, Varanasi, Edition, Reprint 2014, Page No282.

8. Vaidya Yadavji Trikamji Acharya edited Charaka Samhitha of Agnivesa with Ayurvedadipika Commentary Of Sri Chakrapanidatta, Pub-: Choukhamba Surbharathi Prakashan,Varanasi, Reprint 2014, ChikitsaStana, Chapter 5, Sloka No 6, Page No 218

9. Vaidya Jadavji Trikamji Acharya edited Susrutha Samhita with Commentary Nibhanda sangraha of Dalhana, NidanaStana, Chapter 5, Sloka No-19, Pub-: Chaukhamba Surbharathi Prakashan, Varanasi, Edition, Reprint 2014, Page No 451

10. Vaidya Yadavji Trikamji Acharya edited Charaka Samhitha of Agnivesa with Ayurvedadipika Commentary of Sri Chakrapanidatta, Pub-: Choukhamba Surbharathi Prakashan, Varanasi, Reprint 2014, Chikitsa Stana, Chapter 7, Sloka No 19, Page No 451.

11. Pt, Hari Sadashiva Sastri Paradakara edited Ashtanga Hrudaya Of Vagbhata with Commentary of Sarvangasundara of Arunadatta and Ayurveda Rasayana of Hemadri, Pub-; Chaukhamba Surbarati Prakashana, Varanasi Edition, Reprint 2016, NidanaStana, Chapter 14, Sloka No 8-9, Page No 524

12. Prof. Priya Vrat Sharma edited Bhela Samhita, English transltion, Pub -: Choukhamba Surbarati Prakashan, 
Varanasi, Reprint 2008, NidanaStana, Chapter 5, Sloka No 10-11, Page No 151

13. Vaidya Yadavji Trikamji Acharya edited Charaka Samhitha Of Agnivesa with Ayurvedadipika Commentary of Sri Chakrapanidatta, Pub-: Choukhamba Surbharathi Prakashan, Varanasi, Reprint 2014, ChikitsaStana, Chapter 7, Sloka No 37-38, Page No452.

14. Vaidya Jadavji Trikamji Acharya edited Susrutha Samhita with Commentary Nibhandasangraha of Dalhana, NidanaStana, Chapter 5, Sloka No-29, Pub: Chaukhamba Surbharathi Prakashan, Varanasi, Edition, Reprint 2014, Page No 288

15. Pro. K. R. Srikantha Murthy translated Bhavaprakasha of Sri Bhavamisra, Pub-: Chaukhamba Sanskrit Series, Edition 2000, Vol:2, Madhyama Khanda, Chapter 54, Page No 605

16. Vaidya Yadavji Trikamji Acharya edited Charaka Samhitha Of Agnivesa with Ayurvedadipika Commentary of Sri Chakrapanidatta, Pub-: Choukhamba Surbharathi Prakashan, Varanasi, Reprint 2014, Chikitsa Stana, Chapter 7, Sloka No 30, Page No 231

17. Vaidya Yadavji Trikamji Acharya edited Charaka Samhitha Of Agnivesa with Ayurvedadipika Commentary of Sri Chakrapanidatta, Pub-: Choukhamba Surbharathi Prakashan, Varanasi, Reprint 2014, ChikitsaStana, Chapter 7, Sloka No 39, Page No 452

18. Vaidya Yadavji Trikamji Acharya edited Charaka Samhitha of Agnivesa with Ayurvedadipika Commentary of Sri Chakrapanidatta, Pub-: Choukhamba Surbharathi Prakashan, Varanasi, Reprint 2014, ChikitsaStana, Chapter 7, Sloka No 1-42, Page No 452

19. Vaidya Jadavji Trikamji Acharya edited Susrutha Samhita with Commentary Nibhandasangraha of Dalhana, NidanaStana, Chapter 9, Sloka No43, Pub-: Chaukhamba Surbharathi Prakashan, Varanasi, Edition, Reprint 2014, Page No446.

20. Indra Devi Tripathi edited Rasaratna Samuchaya Of Vagbhatacharya with Rasaprabha Hindi Commentary, Published by Chaukhamba Prakashan, Edition 2003, Chapter 20, Sloka197-198.

21. Vaidya Jadavji Trikamji Acharya edited Susrutha Samhita with Commentary Nibhanda sangraha Of Dalhana, NidanaStana, Chapter 10, Sloka No 70-72, Pub-: Chaukhamba Surbharathi Prakashan, Varanasi, Edition, Reprint 2014, Page No 448.
22. http:emedicine.medscape.com/Article/10915775Overview\#A5

23. Vaidya Jadavji Trikamji Acharya edited Susrutha Samhita with Commentary Nibhandasangraha of Dalhana, NidanaStana, Chapter 5, Sloka No 13, Pub-: Chaukhamba Surbharathi Prakashan, Varanasi, Edition, Reprint 2014, Page No 285

\section{Source of Support: Nil Conflict of Interest: None Declared}

How to cite this URL: Sruthi Sreedhar et al: Sidhmakushta: A Disease Review. International Ayurvedic Medical Journal \{online\} 2020 \{cited October, 2020\} Available from: http://www.iamj.in/posts/images/upload/4806_4812.pdf 